Герасимчук В.Г. доктор економ. наук, професор ORCID ID: 0000-000306741814

Начіональний технічний університет Украӥни

"Київський політехнічний інститут імені Ігоря Сікорського"

\title{
МЕХАНІЗМ ПІДВИЩЕННЯ ЕФЕКТИВНОСТІ ЗАЛУЧЕННЯ ІНОЗЕМНИХ ІНВЕСТИЦІЙ В ЕКОНОМІКУ УКРАЇНИ
}

\author{
МЕХАНИЗМ ПОВЫШЕНИЯ ЭФФЕКТИВНОСТИ ПРИВЛЕЧЕНИЯ \\ ИНОСТРАННЫХ ИНВЕСТИЦИЙ В ЭКНОМИКУ УКРАИНЫ
}

\section{MECHANISM OF IMPROVING THE EFFECTIVNESS OF ATTRACTION OF FOREIGN INVESTMENT IN THE ECONOMY OF UKRAINE}

В роботі досліджено роль та значення іноземних інвестицій для розвиту економіки краӥни. 3 метою визначення ефективності інвестиційної політики на сучасному етапі проаналізовано динаміку та структуру іноземних інвестицій в економіку України за 2011 2015 роки. Визначено основні причини зменшення обсягів інвестищій в економіку України та з'ясовано, щуо в багатьох секторах української економіки був відзначений спад в інвестиціях. Це зумовлюється тим, щз, на сьогоднішній день, політична та економічна ситуація сповільнює ріст інвестиційної діяльності не тільки в державі, але $і$ за ї̈ межами.

Проведений аналіз має стати підгрунтям розробки та впровадження ефективного організаційно-правового механізму залучення іноземних інвестицій, який у свою чергу забов'язаний включати законодавчо-правову базу, а також адміністративні структури, методи їх діяльності і використовуваний ними інструментарій залучення ПІІ. Основними складовими комплексного механізму залучення прямих іноземних інвестицій визначено інституціонально-правовий, грошово-кредитний, бюджетно-податковий, територіальноорганізаційний механізми.

Ключові слова: іноземні інвестиції, механізм залучення, динаміка, структура, інвестиційна політика, проблеми, перспективи.

В работе исследовань роль и значение иностранных инвестищий для развития экономики государства. С целью определения эффективности инвестиционной политики на современном этапе проанализирована динамика и структура иностранных инвестиций в экономику Украины за 2011-2015 годы. Определены основные причины снижения объемов инвестииий в экономику Украинь и выяснено, что во многих секторах украинской экономики был отмечен спад в инвестищиях. Это обусловлено тем, что, по сегодняшний день, политическая и экономическая ситуаџия замедляет рост инвестиционной деятельности не только в государстве, но и за ее пределами.

Проведенный анализ должен стать основой разработки и внедрения эффективного организационно-правового механизма привлечения иностранных инвестиций, который в свою очередь должен включать законодательно-правовую базу, а также административные структуры, методы их деятельности и используемый ими инструментарий привлечения ПИИ. Основными составляющими комплексного механизма привлечения прямих иностранных инвестиций выступают институционально-правовой, денежно-кредитный, бюджетно-налоговый, территориально-организационный механизмы.

Ключевые слова: иностранные инвестиции, механизм привлечения, динамика, 
структура, инвестиционная политика, проблемы, перспективы.

This paper is concerned with the investigation of a role and value of the foreign investments to the economic development of a state. It gives a detailed analysis of a composition of the foreign investment and investment behaviour in the economy of Ukraine within 2011-2015 years for the purpose of the performance measurement of the investment policy. The main reasons of decrease in the volumes of investment into economy of Ukraine are determined and it is found out that in many sectors of the Ukrainian economy was marked by a decline in investment. This is due to the fact that, to date, the political and economic situation slows the growth of investment not only in the country but also abroad.

The carried out analysis must be a basis for the development and the efficient introduction into force of a legal and institutional mechanism for the attraction of foreign investments, which in turn should include legislative and regulatory framework, as well as administrative structures, methods of work and the tools they use to attract foreign direct investment. The main components of the complex mechanism of attracting foreign direct investment are the institutional and legal, monetary, fiscal, territorial and institutional mechanisms. , which in turn should include legislative and regulatory framework, as well as administrative structures, methods of work and the tools they use to attract foreign direct investment. The main components of the complex mechanism of attracting foreign direct investment are the institutional and legal, monetary, fiscal, territorial and institutional mechanisms.

Keywords: foreigninvestments, mechanism for the attraction, investment behavior, composition of investment, investment policy, problems and outlooks.

Вступ. Актуальність дослідження проблем залучення іноземного капіталу зумовлена необхідністю підйому економіки на основі зміцнення іiі інвестиційної бази. Соціально-економічний і політичний розвиток України на сучасному етапі спрямований на формування розвиненої відкритої ринкової економіки. Соціально-економічний i політичний розвиток України на сучасному етапі спрямований на формування розвиненої відкритої ринкової економіки. Також найважливішою умовою залучення зарубіжних інвестицій в нашу країну $\epsilon$ формування ефективного механізму підвищення ефективності залучення іноземних інвестицій в економіку України та підвищення рівня інвестиційної привабливості. Актуальність теми дослідження визначається також необхідністю залучення іноземних інвестицій для вирішення як стратегічних, так і поточних завдань фінансово-економічного і соціального розвитку України.

Слід зазначити, що питання, пов'язані з формуванням ефективної інвестиційної політики держави та дієвого механізму залучення іноземних інвестицій в економіку Українирозглядається в роботах таких вчених, як В.В. Пилипів [6], Г. Коваль [5], О.О. Бондаренко та К.С. Нижник [3], Л.О. Чернишова та В. В. Сазанова [8] та інших.

Однак у зв'язку із загостренням політичної та економічної кризи, продовженням військових дій на Сході, та викликаним цими явищами різким скороченням обсягів іноземних інвестицій доцільність подальшої наукової розробки проблеми іноземних інвестицій залишається незмінною.

Постановка завдання. Такий стан проблеми детермінує потребу аналізу особливостей залучення іноземних інвестицій в економіку України на сучасному етапі та розроблення ефективного та діючого механізму 
інвестиційної політики. Теоретичні висновки мають бути зроблені з позицій збереження надбань сучасної економічної науки.

Мета статті - проаналізувати особливості залучення іноземних інвестицій в українську економіку i розробка науково-обгрунтованих рекомендацій щодо формування i вдосконалення механізму залучення іноземних інвестицій.

Методологія. У процесі роботи використовувалися такі загальнонаукові та спеціальні методи і прийоми дослідження, як теоретичний аналіз і синтез, методи групування, моделювання, порівняння, економіко-статистичні, графічні, а також методи систематизації та наукового узагальнення.

Результати дослідження. Терміни «інвестиції», «інвестування», «інвестиційний процес», «інвестиційна діяльність», «інвестиційна політика» стали вживатись у нашій країні порівняно нещодавно. Інвестиції- грошові, майнові, інтелектуальні цінності, що вкладають в об'єкти підприємницької та інших видів діяльності 3 метою отримання прибутку або досягнення соціального ефекту; капітальні вкладення в розвиток виробництва чи невиробничі сфери [4, с. 187].

Іноземні інвестиції - це цінності, що іноземні інвестори вкладають в об’єкти інвестиційної діяльності в Україні з метою одержання прибутку або досягнення соціального ефекту [3, с.90].

Найбільш раціональною та ефективною формою іноземних інвестицій є прямі іноземні інвестиції, тобто довгострокові фінансові вкладення в національну економіку.

Прямі іноземні інвестиції - «інвестиції, що викликають тривалий інтерес до підприємства, яке діє за межами економіки інвестора». Згідно 3 методологією МВФ ПІІ - це закордонні інвестиції розміром понад $40 \%$ статутного капіталу, що надає зацікавленій стороні право на участь в управлінні підприємством [5, с.49].

Як зазначає В. В. Пилипів, прямі іноземні інвестиції (ПІІ) являють собою прямі капіталовкладення, що здійснюються іноземними (міжнародними) операторами в юридичні особи певної країни[6, с.5].

Аналіз світового досвіду підтверджує, що іноземні інвестиції допомагають вирішенню проблеми недостатності власних грошей як джерела фінансування. При їх ефективному використанні країна може не тільки компенсувати нестачу внутрішніх інвестиційних ресурсів, а ще й підвищити ефективність виробництва та конкурентоспроможності вітчизняної продукції завдяки введенню новітніх технологій та аналізу прогресивного досвіду управління інших країн світу [8, с.62].

Основне завдання іноземних інвестицій полягає не тільки в забезпеченні додаткових фінансових вкладень в економіку, але і в задоволенні потреби приймаючої країни в нових прогресивних методів праці і засоби виробництва. При цьому в країні-реципієнті формуються нові виробничі відносини, що дозволяють більш ефективно використовувати наявний іноземний капітал. Збільшення іноземних інвестицій $\epsilon$ не тільки базисом відновних процесів, але і фактором зниження безробіття, зростання податкових надходжень до 
бюджетів, підвищення рівня менеджменту, посилення конкуренції в національній економіці, розвитку соціальної сфери.

Розглянемо прямі іноземні інвестування за період з 2011 по 2015 роки, за даними Державної Служби Статистики України. На рис.1 представимо динаміку інвестицій в економіку України за досліджуваний період:

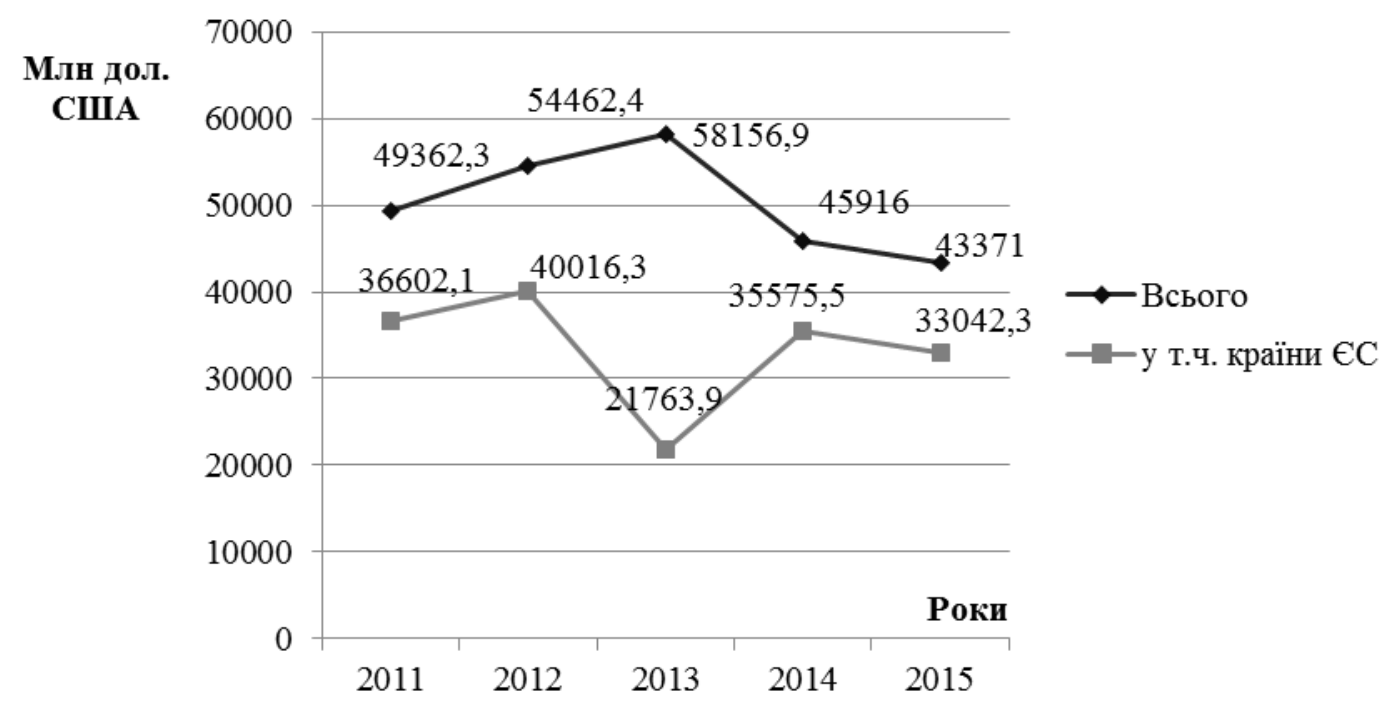

Рис.1. Прямі іноземні інвестиції у Україну за 2011-2015 роки [2]

Отже, як бачимо з рис. 1, загальний обсяг іноземних інвестицій у 2011 році становив 49362,3 млн. дол., у 2012 році відповідно - 54462,4 млн. дол., у 2013 році 58156,9 млн. дол., тобто слід відмітити, що протягом трьох років, до 2014 р., надходження ПІІ було регулярними та стабільними. Темпи росту іноземних вкладень у 2012 та 2013 роках відповідно до 2011 року становили $110,3 \%$ та $117,8 \%$.

Починаючи з 2014 року загальний обсяг іноземних інвестицій скоротився проти 2011 року на 3446,3 млн. дол. і становив 45916 млн. дол., у 2015 році скорочення проти 2011 року становить 5990,9 млн. дол., і становить - 43371,4 млн. дол. Відповідно темпи росту у 2014 та 2015 роках становили 93,0\% та $87,9 \%$

Причин такого сповільнення багато: стан війни у якому перебуває Україна, макроекономічне гальмування, зупинення низки промислових підприємств, стрімка девальвація та інфляція, зниження рівня споживання.

Важливою складовою аналізу інвестиційних процесів є дослідження географічної структури залучених інвестицій. Відмітимо, що остання формується під впливом багатьох чинників, серед головних - розвиток зовнішньоекономічних зв'язків зі стратегічними партнерами (до 2002 р. цим партнером були США та Росія, сьогодні головним стратегічним економічним партнером країни $є \quad € C)$ та потреба у диверсифікації міжнародної інвестиційної діяльності. 
На рис. 2 наведемо розподіл прямих іноземних інвестицій в Україну за основними країнами - інвесторами протягом 2013-2015 років.

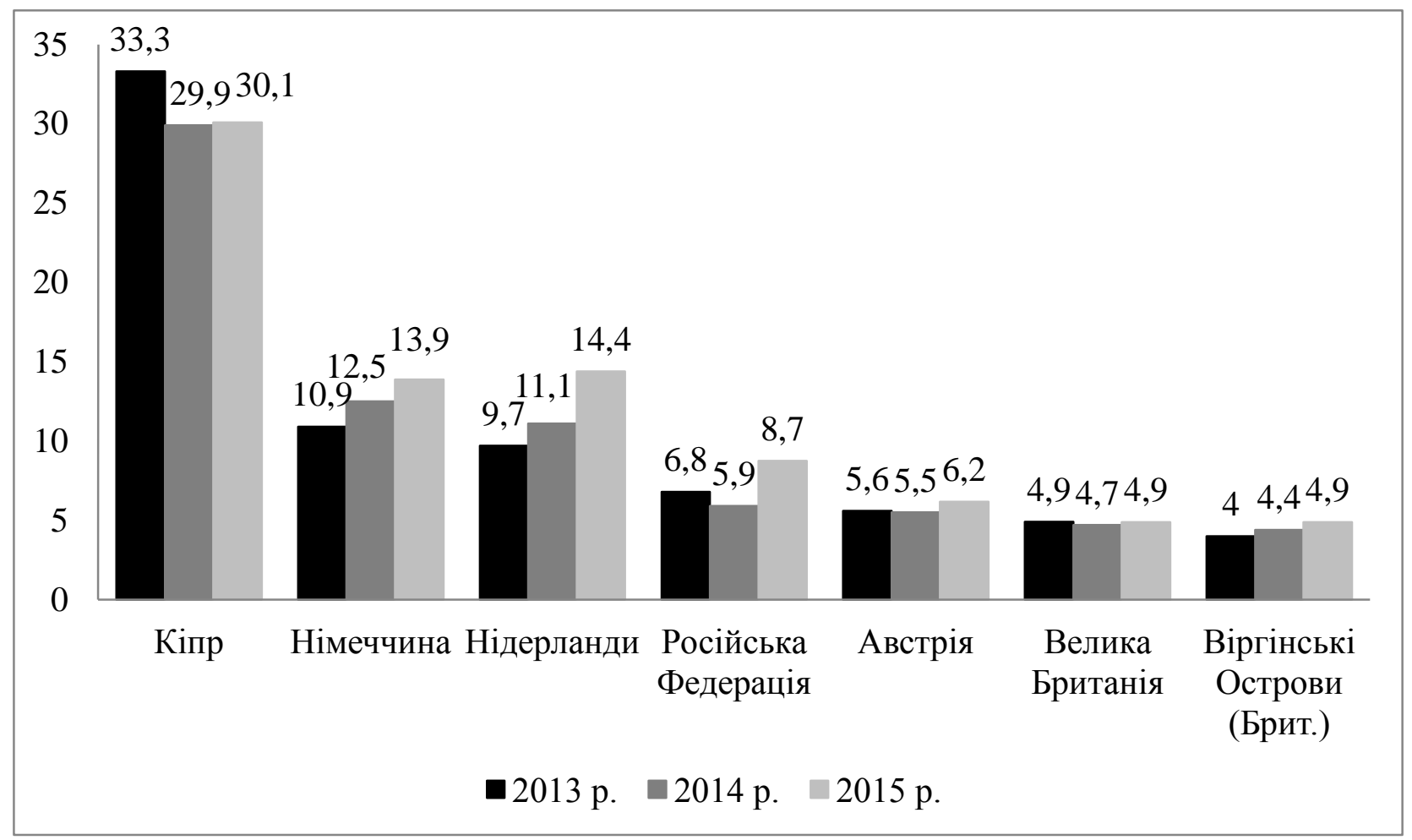

Рис. 2. Розподіл прямих інвестицій в Україну за основними країнамиінвесторами (у\% до загального обсягу)[2]

Якщо звернутися до структури основних країн-інвесторів у вітчизняну економіку, то слід зазначити, що до десятки основних країн-інвесторів, які вкладають найбільше коштів в українську економіку і на які припадає понад $82 \%$ загального обсягу прямих іноземних інвестицій, входять такі країни, як Кіпр (обсяг інвестицій у 2015 р. - 11744,9 млн. дол.), Нідерланди (5610,7 млн. дол.), Німеччина (5414,3млн. дол.), Росія (3392,1 млн. дол.), Австрія (2402,4 млн. дол.), Велика Британія (1852,5млн. дол.), Віргінські Острови (1798,9 млн. дол.), Франція (1528,1 млн. дол.), Швейцарія $(1364,2$ млн. дол.) та Італія $(972,4)$.

Не залишаються поза увагою особливості іноземного інвестування 3 огляду на походження основної частки вкладених капіталів із офшорних зон. На ці країни припадає понад 58 \% накопичених у вітчизняній економіці прямих іноземних інвестицій.

Сформована ситуація не $\epsilon$ сприятливою, так як в основному ПІІ надходять 3 офшорних юрисдикцій, і по суті не $\epsilon$ іноземними.

Зокрема, тільки частка Кіпру в сукупних обсягах ПІІ в Україну становила 27,7 \%, при цьому вона дещо знизилася порівняно з 2013 р., коли становила $33,3 \%$.

Забезпечити залучення ПІІ в економіку України в масштабах і структурі, що відповідають зростаючим потребам та інтересам країни, а також національним i регіональним пріоритетним цілям, неможливо без 
вдосконалення організаційно-економічного механізму їх регулювання та залучення, що включає законодавчо-правову базу, а також адміністративні структури, методи їх діяльності i використовуваний ними інструментарій залучення ПІІ.

Механізм регулювання та залучення ПІІ слід розглядати як сукупність заходів та інструментів, спрямованих не тільки на стимулювання припливу ПІІ в країну, але й на оптимізацію цього процесу - упорядкування структури, форм і спрямованості іноземних інвестицій у відповідності 3 потребами i стратегічними інтересами нашої країни.

Основними складовими комплексного механізму залучення прямих іноземних інвестицій виступають інституціонально-правовий, грошовокредитний, бюджетно-податковий, територіально-організаційний механізми (рис. 3).

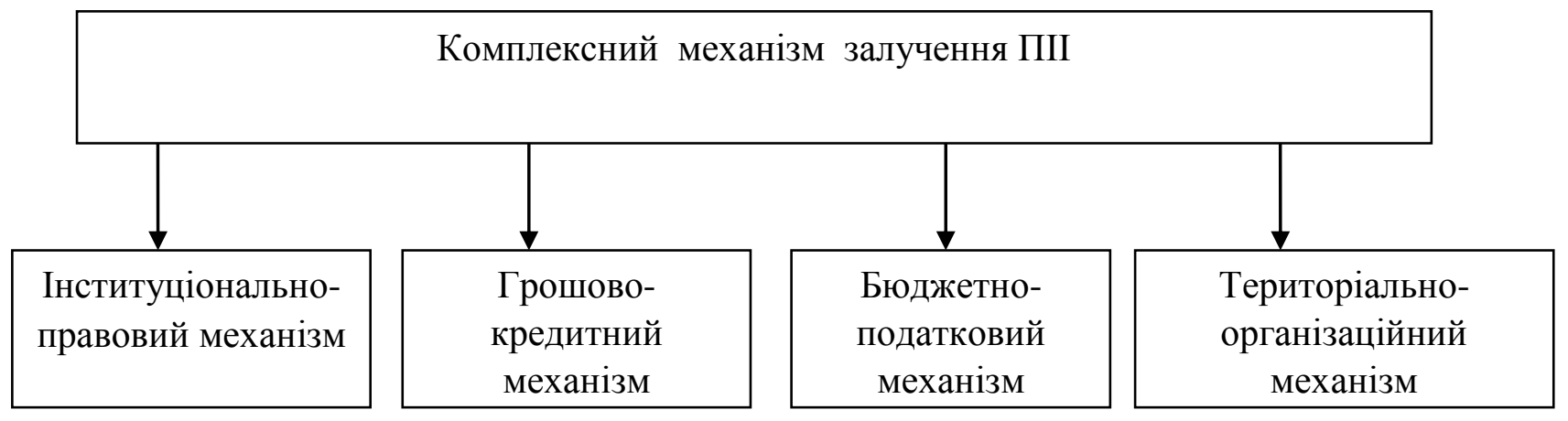

Рис. 3. Характеристика основних складових комплексного механізму залучення прямих іноземних інвестицій [2]

Інституційно-правовий механізм покликаний забезпечити формування належного правового середовища, необхідного для залучення іноземних інвестицій 3 урахуванням національного та світового досвіду, а також міжнародних зобов'язань України.

Однією 3 найважливіших складових механізму є грошово-кредитний механізм, метою якого є формування ефективної національної й регіонально політики щодо фінансової підтримки інвестиційної діяльності, що потребує узгодження усіх видів економічної політики. Одними 3 основних факторів розширення масштабів інвестиційної діяльності $є$ стимулювання довгострокового банківського кредитування реального сектора економіки i залучення коштів населення. Рішення цієї задачі вимагає впровадження механізму ефективного захисту прав кредиторів і прозорого порядку реалізації заставного майна, підвищення рівня концентрації банківського капіталу, стимулювання залучення грошових внесків населення, уведення механізму іпотечного кредитування, стимулювання надходження іноземного капіталу в банківську сферу [7, с.148].

Бюджетно-податковий механізм передбачає вдосконалення фіскального стимулювання інвестиційної діяльності та амортизаційної політики, а також збільшення обсягів амортизаційних відрахувань для здійснення інвестиційної 
діяльності в промисловому секторі економіки, зокрема, через використання прискореної амортизації. Податкова політика України має перейти від домінування фіскальних пріоритетів до реалізації стимулюючого потенціалу у спосіб надання податкових пільг і преференцій для промисловості.

Одним із основних напрямів удосконалення територіальноорганізаційного механізму $\epsilon$ створення певних преференційних умов на окремих територіях. У світовій практиці особливу увагу приділено таким інструментам і механізмам державної інвестиційної політики, як спеціальні правові режими економічної діяльності, що передбачають застосування для частини суб'єктів господарювання впродовж визначеного часу особливих, відмінних від загальнонаціонального режиму, більш преференційних умов діяльності.

Висновки. Наукова новизна дослідження полягає в систематизації результатів аналізу особливостей інвестиційної політики держави на сучасному етапі та розробленні на основі проведеного аналізу комплексного механізму залучення прямих іноземних інвестицій, що дозволяє узагальнити ряд висновків:

1. Залучення прямих іноземних інвестицій а економіку України повинно бути одним із пріоритетних напрямів розвитку української економіки. Ефективність і стан інвестиційної діяльності в Україні залежить, перш за все, від відповідної державної i регіональної інвестиційної політики, результативність якої зумовлюється наявністю чіткого організаційноекономічного механізму ії реалізації.

2. Аналіз обсягу, динаміки, регіональної та галузевої структури прямих іноземних інвестицій в українську економіку за останні роки свідчать про те, що вони не стали повноцінним джерелом інноваційного розвитку. За останні три роки потік іноземних інвестицій в економіку зменшився, що було спричинене глобальними кризовими явищами та нестабільністю економіки України. Хоча в деякі галузі обсяг іноземних інвестицій збільшується (харчова, хімічна промисловість; виробництво меблів та ремонт машин).

3. Для того щоб зростали обсяги i поширювалося застосування іноземних інвестицій, потрібно здійснити оцінку впливу факторів інвестиційного середовища та клімату на інвестиційні процеси. Досягнення високого рівня інвестиційної привабливості - це непростий, а часто дуже трудомісткий процес, що потребує в окремих випадках серйозної мобілізації зусиль. Інвестиційна привабливість не формується відразу, для іiі розвитку потрібно наявність багатьох факторів - від географічного розташування трудових ресурсів до рівня розвиненості інфраструктури та соціальнополітичної обстановки в даній країні. Україна, по ряду показників, $\epsilon$ інвестиційно-привабливою країною. Разом 3 тим, динаміка надходження іноземних інвестицій у вітчизняну економіку свідчить, що інвестиційна привабливість нашої країни недостатньо висока. Особливо гостро ця проблема проявляється в умовах соціально-економічної та економічної кризи.

Результати дослідження мають теоретичне та практичне значення, 
оскільки можуть бути використані 3 метою створення умов для реалізації ефективної інвестиційної політики та активізації інвестиційного процесу в Україні на етапі виходу з кризи.

Результати дослідження можуть бути використані в перспективних подальших наукових розробках при вивченні проблем підвищення ефективності інвестиційної політики держави, зокрема обгрунтування методологічних основзалучення іноземних інвестицій в економіку України.

\section{Література:}

1. Закон України «Про інвестиційну діяльність» № 1561-XII від 19.11.1991 р. [Електронний ресурс]. - Режим доступу: http://zakon4.rada.gov.ua.

2. Державна служба статистики України : Електронний ресурс. - Режим доступу: www.ukrstat.gov.ua.

3. Бондаренко О. О. Залучення іноземних інвестицій як джерело економічного зростання [Текст] / О. О. Бондаренко, К. С. Нижник // Вісник Київського національного університету технологій та дизайну. - 2014. - № 3 (77). - С. 88-95.

4. Бюлетень Національного банку України / Національний банк України. - 2014. № 2 (251). - Лютий. -217 с.

5. Коваль Г. Прямі іноземні інвестиції в країнах із перехідною економікою ( на прикладі Польщі) / Г. Коваль // Україна та Польща: минуле, сьогодення, перспективи. - 2013. - Т. 2. - С. 49-53. - Режим доступу: http://nbuv.gov.ua/UJRN/UPmcp_2013_2_14

6. Пилипів В. В. Прямі іноземні інвестиції та процеси регіонального відтворення / В. В. Пилипів // Інвестиції: практика та досвід. - 2011. - № 8. - С. 5-7. - Режим доступу:http://nbuv.gov.ua/UJRN/ipd_2011_8_4

7. Федоренко В.Г. Інвестознавство: підручник ; 2-ге вид., перероб. / В.Г. Федоренко. - К. : МАУП. - 2012. - 512 с.

8. Худавердієва В.А. Стратегія залучення іноземних інвестицій у економіку України / В.А. Худавердієва // Фінанси України. - 2014. - № 6 - С. 62-71

9. Чернишова Л.О. Особливості залучення та стимулювання іноземного інвестування в Україні / Л. О. Чернишова, В. В. Сазанова // Бізнес Інформ. - 2016. - №4. - С. $87-90$ 